\title{
Hepatic steatosis in HIV-HCV coinfected patients receiving antiretroviral therapy is associated with HCV-related factors but not antiretrovirals
}

Valérie Martinez ${ }^{1,2^{*}}$, Thi Dieu Ngan TA ${ }^{3 \dagger}$, Zahra Mokhtari ${ }^{4 \dagger}$, Marguerite Guiguet ${ }^{5}$, Patrick Miailhes $^{6}$, Marc-Antoine Valantin ${ }^{2,5}$, Fréderic Charlotte ${ }^{7}$, Philippe Bertheau ${ }^{8}$, Jean-Michel Molina ${ }^{9}$, Christine Katlama ${ }^{2,5}$ and Eric Caumes ${ }^{2,5}$

\begin{abstract}
Background: In HIV and hepatitis C virus (HCV) coinfected patients, the role of antiretroviral therapy (ART) on hepatic steatosis (HS) remains controversial.

Methods: HIV/HCV coinfected patients receiving ART and previously untreated for HCV who underwent a liver biopsy were included. Cumulative duration of exposure to each antiretroviral was recorded up to liver biopsy date. Logistic regression analyses evaluated factors associated with steatosis and its severity.

Results: 184 patients were included: median age 41 years, 84\% male, 89\% Caucasian, 61\% with a past history of intravenous drug use. HCV genotypes were 1 (55\%), 2 (6\%), 3 (26\%), and 4 (13\%). Median HCV-RNA was $6.18 \log _{10}$ $\mathrm{IU} / \mathrm{ml}$. HIV-RNA was undetectable $(<400$ copies $/ \mathrm{ml})$ in $67 \%$ of patients. Median CD4 count was $321 / \mathrm{mm}^{3}$. All patients had been exposed to nucleoside reverse transcriptase inhibitors (median cumulative exposure 56 months); 126 received protease inhibitors (23 months), and 79 non-nucleoside reverse transcriptase inhibitors (16 months). HS was observed in 102 patients (55\%): $41 \%$ grade 1; 5\% grade 2, and $9 \%$ grade 3 . In multivariate analysis, HCV genotype 3 and HCV viral load were moderately associated with mild steatosis but strongly with grade 2-3 steatosis. After adjustment for the period of biopsy, no association was detected between HS and exposure to any antiretroviral class or drug, or duration of ART globally or comparing genotype 3 to others.
\end{abstract}

Conclusions: Among our ART-treated HIV-HCV cohort predominantly infected with genotype 1,55\% of patients had HS which was associated with HCV-related factors, but not ART class or duration of exposure.

Keywords: HIV, HCV, steatosis, antiretroviral drugs, genotype 3

\section{Introduction}

As a result of shared transmission routes, hepatitis $C$ virus $(\mathrm{HCV})$ infection is common in patients infected with human immunodeficiency virus (HIV) [1-3]. In the USA and Western Europe, at least 30\% of HIV-infected patients are also infected with HCV [1-4]. The immunosuppression

\footnotetext{
* Correspondence: valerie.martinez@abc.aphp.fr

${ }^{\dagger}$ Equal contributors

'Service de Médecine Interne et Immunologie Clinique, Assistance PubliqueHôpitaux de Paris, INSERM UMR_S 996, Université Paris Sud, Hôpital Antoine Béclère, 157, rue de la Porte de Trivaux, 92141, Clamart, France

${ }^{2}$ Service des Maladies Infectieuses et Tropicales, Hôpital Pitié-Salpêtrière, Université Pierre et Marie Curie, APHP, 45/83 Boulevard de l'Hôpital, 75013, Paris, France

Full list of author information is available at the end of the article
}

induced by HIV accelerates the natural history of HCVrelated liver disease and the progression of chronic hepatitis $C$ to cirrhosis and end-stage hepatic disease [5-10].

The introduction of highly active antiretroviral therapy has been associated with a dramatic decline in the morbidity and mortality related to specific HIV complications, whereas that related to liver disease has increased significantly in coinfected patients $[1,6,11-13]$. The relative increase in morbidity and mortality due to liver disease in the HIV population is a composite of accelerated liver disease progression in HCV patients and extended survival of these individuals due to the benefit of antiretroviral therapy (ART).

Hepatic steatosis (HS), defined by the accumulation of lipid droplets in hepatocytes, is present in 24-75\% of HIV 
and HCV coinfected patients [12,14-23]. Some factors contributing to the development of HS in the general population, such as visceral obesity, alcohol consumption, hypertriglyceridemia, hypertension and diabetes mellitus remain hugely discrepant during coinfection [24-28]. In HIV and HCV coinfected patients, HS may occur as a result of the HIV infection or as a consequence of concomitant $\mathrm{HCV}$ infection, as well as metabolic factors such diabetes, obesity or antiretroviral drugs which could induce metabolic syndrome, lipodystrophy or lactic acidosis due to mitochondrial damage [12,14,15,18-20,22,29-32]. Nevertheless, the role of ART, particularly stavudine exposure, remains controversial. Moreover, in some studies, HS appears to be more common and severe in coinfected than in HCV-monoinfected patients $[16,22]$ and influence by the viral genotype $[16,22]$. Borghi et al., showed previously that HIV related steatosis increase in genotype 3 patients and a putative role of ART in patients infected by $\mathrm{HCV}$ genotype other than 3 [23]. Other factors besides immunesuppression account for faster progression to ESLD in coinfected patients (i.e. HIV hepatocyte infection, drug liver toxicity).

To assess the prevalence and risk factors of HS, particularly characteristics associated with severity, we reviewed the epidemiological, clinical and biological data of HIV-HCV coinfected patients receiving ART, before $\mathrm{HCV}$ therapy and at the time of liver biopsy. Moreover, we compared the effect of ART according to the genotype.

\section{Patients and Methods \\ Patients}

For this study, HIV-HCV coinfected patients were retrospectively screened in histopathology databases of two hospitals. All HIV-infected patients with detectable $\mathrm{HCV}$ RNA load (qualitative or quantitative detection), receiving ART but naive of HCV-specific therapy and who underwent a liver biopsy between January 1995 and January 2008, were included. When repeated liver biopsies were performed, only data associated with the first one was studied.

Patients were excluded if they were positive for hepatitis B surface antigen, had a negative plasma HCV RNA load, or other chronic liver diseases, such as autoimmune hepatitis, hemochromatosis, Wilson's disease or alpha-1 antitrypsin deficiency. All patients have been tested for all of these parameters and the patients included were negative.

At the day of liver biopsy, the following variables were assessed: age, gender, ethnicity, alcohol (reported by physician in the medical report, but no data about the quantity consumed daily), intravenous drug abuse, duration of documented $\mathrm{HIV}$ and $\mathrm{HCV}$ infections, risk factors for viral transmission, CD4 cell count, HIV and HCV plasma levels,
HCV genotype, fasting glycemia, total cholesterolemia and triglyceridemia, alanine aminotransferase (ALT), aspartate aminotransferase (AST), gammaglutamyl transferase (GGT) and alkaline phosphatase. Measure of insulinemia, not performed in clinical practice, was not available in this retrospective study, nor measure of weight, body mass index and waist circumference which were not recorded in the medical report. Metabolic parameters were also recorded for each patient on a fasting state. For the purposes of this study, metabolic syndrome was defined as triglycerides $>1.7 \mathrm{mmol} / \mathrm{l}$ and glycemia $\geq 5.6 \mathrm{mmol} / \mathrm{l}$ as recommended by the International Diabetes Federation 2005 and diabetes as a fasting glycemia $>7 \mathrm{mmol} / \mathrm{l}$ and excluded waist circumference [33].

HCV RNA detection was performed using a signal amplification nucleic acid probe assay (bDNA 3.0, Bayer diagnostics, Tarrytown NY) and was expressed in KIU/ml. All biological data were assessed directly to the data system of the different laboratories of the 2 hospitals. All of the parameters collected were routinely performed in HIV-HCV patients who underwent a liver biopsy and were assessed on the day of biopsy or during the week before.

History of antiretroviral therapy was assessed in the medical report and from our database (Nadis software ${ }^{\circledR}$ ). The cumulative duration of exposure to each drug and class of drugs was recorded for each patient up to the date of liver biopsy. As patients could have received more than one ART regimen, and because of the large diversity of regimens available in France, it would be impossible to select specific drug combinations for analysis. Therefore, we hypothesized that a relationship between a combination of drugs and severity of HS would be evident by studying each component of the combination.

\section{Histologic evaluation}

Percutaneous or transjugular liver biopsy specimens were fixed in formalin and embedded in paraffin. Minimal size was $10 \mathrm{~mm}$ and contained at least 6 portal spaces, excepted if cirrhosis. Sections $4 \mu \mathrm{m}$ thick were stained with hematoxylin and eosin, with picrosirius stain for collagen and Perls' stain for iron. All liver biopsy specimens were evaluated by two experienced pathologists, one in each hospital (F.C. or P.B.).

The grade of activity and the stage of fibrosis were evaluated according to the METAVIR scale [34]. Necroinflammatory activity was graded A0 (none), A1 (mild), A2 (moderate) or A3 (high). The degree of portal and septal fibrosis was assessed as F0 (none), F1 (portal fibrosis without septa), F2 (portal fibrosis with a few septa), F3 (portal fibrosis with numerous septa) or F4 (cirrhosis). HS was evaluated and graded as proposed by Brunt et al. [33]: grade 0 , none; grade 1 , steatosis involving $<33 \%$ of hepatocytes; grade $2,33-66 \%$ and grade $3,>66 \%$. HS was defined as mild (grade 1 ) or severe (grade $2-3$ ). 


\section{Statistical analysis}

Median and interquartile ranges (IQRs) described continuous variables. Comparisons between patients found with and without steatosis were performed using KruskalWallis or Wilcoxon tests for quantitative variables, and $\chi^{2}$ test or Fisher's exact test for qualitative variables. Logistic regression analyses were used to identify determinants of liver steatosis, and polytomous logistic regression analyses evaluated factors associated with the presence of mild or severe steatosis.

Exposure to ART was studied after adjustment for the period of biopsy (1995-1998, 1999-2001, 2002-2008). The periods were chosen at the time of the statistical analysis according to the introduction of drugs such as abacavir in 1999 and tenofovir in 2002 to show an impact of the use of more "metabolic friendly" drugs. Exposure to ART and cumulative exposure duration (per 1 year increased) were evaluated globally for all patients and according to genotype: genotype 3 compared to others.

Variables with $p<0.15$ in univariate analyses were included in the final model. Analyses were processed with the use of SAS software (SAS Institute, Cary, North Carolina, USA).

\section{Results}

\section{Study population}

Between January 1995 and January 2008, 250 HIV-HCV coinfected patients who underwent a liver biopsy and fulfilled all inclusion criteria were evaluated. Sixty-six patients were not analyzed for the following reasons corresponding to exclusion criteria: hepatitis $\mathrm{B}$ coinfection $(n=28)$, loss of medical records $(n=8)$ or no ART at the time of biopsy $(n=30)$. Therefore, 184 patients were included. Demographic and biological characteristics are summarized in Table 1.

No correlation was observed between the duration of HIV infection and CD4 cell count in this cohort of ARTtreated patients. HIV plasma viral load was undetectable $(<400$ copies/ml) in 119 out of the 178 (67\%) evaluable patients and median HIV viral load on average was 3.93 $\log _{10}$ copies $/ \mathrm{ml}$ for the remaining $33 \%$ patients. The median $\mathrm{HCV}$ viral load was $6.18 \log _{10} \mathrm{IU} / \mathrm{ml}$ (IQR 5.76$6.60)$ in the 148 (80\%) patients with quantificative HCV values. The other patients $(n=36)$ had only a positive HCV RNA without quantification.

All patients had been exposed to a nucleoside reverse transcriptase inhibitor (NRTI), including zidovudine $(\mathrm{n}=144)$, lamivudine $(\mathrm{n}=161)$, stavudine $(\mathrm{n}=114)$, zalcitabine $(n=22)$, didanosine $(n=105)$, tenofovir $(n=24)$ and abacavir $(\mathrm{n}=24) ; 126$ patients had received protease inhibitors (PI), including ritonavir as boosted-PI $(n=59)$, indinavir $(n=68)$, nelfinavir $(n=47)$, saquinavir $(n=16)$, lopinavir $(\mathrm{n}=17)$ and atazanavir $(\mathrm{n}=8)$; and 79 patients had received
Table 1 Characteristics of HIV-HCV coinfected patients treated with antiretroviral therapy at the time of liver biopsy (parameters collected the day of the liver biopsy or during the week before)

\begin{tabular}{|c|c|}
\hline & $n=184$ \\
\hline Median age at biopsy (IQR), years & $41(36-45)$ \\
\hline Male, n (\%) & $154(84)$ \\
\hline \multicolumn{2}{|l|}{ Ethnicity, n (\%) } \\
\hline Caucasian & $163(89)$ \\
\hline Black & $21(11)$ \\
\hline Intravenous drug use, n (\%) & $127(61)$ \\
\hline Alcohol use, n (\%)* & $67(36)$ \\
\hline Median duration of HIV diagnosis (IQR, years & $11(7-14)$ \\
\hline Median CD4 cell counts/mm³ (IQR) & $321(227-461)$ \\
\hline Undetectable HIV RNA ${ }^{+}$, n (\%) & $119(67)$ \\
\hline \multicolumn{2}{|l|}{ HCV genotype ${ }^{++}, \mathrm{n}(\%)$} \\
\hline 1 & $98(55)$ \\
\hline 2 & $10(6)$ \\
\hline 3 & $47(26)$ \\
\hline 4 & $24(13)$ \\
\hline Median HCV RNA (IQR), $\log _{10} \mathrm{KIU} / \mathrm{ml}^{+++}$ & $6.18(5.76-6.60)$ \\
\hline \multicolumn{2}{|l|}{ Median laboratory variables (IQR), U/I } \\
\hline $\mathrm{ALT}$ & $83(47-128)$ \\
\hline AST & $65(43-97)$ \\
\hline Alkaline phosphatase & $89(71-113)$ \\
\hline GGT & $80(42-160)$ \\
\hline Median glycemia (IQR), mmol/l & $4.8(4.3-5.3)$ \\
\hline Glycemia $\geq 5.6 \mathrm{mmol} / \mathrm{I}^{+}, \mathrm{n}(\%)$ & $33(19)$ \\
\hline Glycemia $\geq 7.0 \mathrm{mmol} / \mathrm{I}^{+}, \mathrm{n}(\%)$ & $7(4)$ \\
\hline Median total cholesterol (IQR), mmol// & $4.20(3.54-5.10)$ \\
\hline Median triglyceridemia (IQR), mmol// ${ }^{\circ}$ & $1.49(0.99-2.10)$ \\
\hline Triglyceridemia $\geq 1.7 \mathrm{mmol} / \mathrm{I}^{+}, \mathrm{n}(\%)$ & $60(36)$ \\
\hline Median duration of antiretroviral therapy (IQ & $58(28-94)$ \\
\hline
\end{tabular}

Median cumulative exposure to antiretrovirals (IQR), months

\begin{tabular}{ll}
\hline NRTI & $56(28-90)$ \\
\hline NNRTI & $16(9-31)$ \\
\hline PI & $23(12-40)$
\end{tabular}

Combination of ART at liver biopsy, $\mathrm{n}(\%)$

\begin{tabular}{ll}
\hline $2 \mathrm{NRTI}+1 \mathrm{PI}$ & $93(51)$ \\
\hline $2 \mathrm{NRTI}+1$ NNRTI & $36(20)$ \\
\hline 1 or $2 \mathrm{NRTI}$ & $31(16)$ \\
\hline $3 \mathrm{NRTI}$ & $17(9)$ \\
\hline Other regimens & $7(4)$
\end{tabular}

${ }^{+}$proportions calculated on available data.

${ }^{+}$Data missing for 6 patients; ${ }^{++}$Data missing for 5 patients; ${ }^{+++}$Data missing for 36 patients; ${ }^{\circ}$ Data missing for 11 patients; ${ }^{\circ}$ Data missing for 18 patients. *Alcohol: no quantification was available.

Abbreviations: ALT, alanine transaminase; AST, aspartate aminotransferase; GGT, gamma-glutamyl transpeptidase; IQR, interquartile range; NNRTI, nonnucleoside reverse transcriptase inhibitor; NRTI, nucleoside reverse transcriptase inhibitor; PI, protease inhibitor. 
non-nucleoside reverse transcriptase inhibitors (NNRTI), including efavirenz $(n=51)$ and nevirapine $(n=44)$.

\section{Histologic findings}

Overall, 102 (55\%) out of the 184 patients had HS. Steatosis was grade 1 in $76(41 \%)$ patients, grade 2 in $10(5 \%)$, and 3 in $16(9 \%)$. Macrovesicular fatty changes were observed in 56 patients (55\%), microvesicular in $10(10 \%)$, and mixed form in 36 (35\%). Fibrosis was present in 163 patients (89\%) with METAVIR F1 score in 66 (36\%), F2 in 53 (29\%), F3 in 39 (21\%) and F4 in 4 (2\%). Necroinflammatory activity was detected in 164 out of the $184(89 \%)$ patients with A1 in 109 (59\%), A2 in 50 (27\%) and A3 in 5 (3\%).

\section{Factors associated with hepatic steatosis}

Comparison of parameters in patients with or without HS are presented in Table 2. In univariate analysis, intravenous drug use $(p=0.05)$ and HCV genotype $3(p=0.005)$ were strongly linked with HS. The median HCV viral load was significantly higher in patients with HS compared with those without $(p=0.003)$. HS was also associated with increased levels of ALT, AST and decreased levels of serum total cholesterol, but not with triglyceridemia nor available parameters of metabolic syndrome (only 7 patients have a glycemia $>7 \mathrm{mmol} / \mathrm{l}$ with mild steatosis for 6 patients and 1 had no steatosis) (Table 2).

Also, there was no association with CD4 cell count or an undetectable HIV viral load. Similar results were found in patients with mild versus severe steatosis.

HS was also associated with fibrosis (Figure 1). Thus, the frequency of HS increased with the stages of fibrosis, with $76 \%, 54 \%, 32 \%$, and $28 \%$ of patients without steatosis having fibrosis scores of F0, F1, F2, and F3-F4, respectively (Cochran-Armitage trend test, $p<0.0001$ ). However, the severity of steatosis was not different among patients presenting fibrosis scoring F1, F2, or F3-F4. No association was observed between HS and necroinflammatory activity.

Table 2 Comparison of various parameters in patients with mild ( $<33 \%$ of hepatocytes affected) or severe ( $>33 \%$ of hepatocytes affected) steatosis and those without steatosis (univariate analysis)

\begin{tabular}{|c|c|c|c|c|c|c|c|}
\hline & $\begin{array}{l}\text { No steatosis } \\
(n=82)\end{array}$ & $\begin{array}{l}\text { Steatosis } \\
(n=102)\end{array}$ & $\begin{array}{l}\text { Mild steatosis } \\
(n=76)\end{array}$ & $\begin{array}{l}\text { Severe steatosis } \\
(n=26)\end{array}$ & $p^{a}$ & $p^{\mathrm{b}}$ & $p^{c}$ \\
\hline Median age (IQR), yrs & $40(36-45)$ & $41(37-45)$ & $41(36-45)$ & $41(37-48)$ & 0.38 & 0.66 & 0.81 \\
\hline Male gender, n (\%) & $66(80)$ & $88(86)$ & $67(88)$ & $21(81)$ & 0.32 & 0.39 & 0.34 \\
\hline IVDU, n (\%) & $50(62)$ & $77(76)$ & $54(71)$ & $23(88)$ & 0.05 & 0.03 & 0.11 \\
\hline Alcohol use, n (\%) & $29(35)$ & $38(37)$ & $29(38)$ & $9(35)$ & 0.88 & 0.92 & 0.82 \\
\hline Median duration of HIV (IQR), yrs & $10(5-14)$ & $12(8-14)$ & $12(8-15)$ & $11(7-13)$ & 0.17 & 0.23 & 0.30 \\
\hline $\begin{array}{l}\text { Median CD4 cell count (IQR), } \\
/ \mathrm{mm}^{3}\end{array}$ & $346(228-560)$ & $308(227-423)$ & $305(227-435)$ & $313(191-398)$ & 0.10 & 0.24 & 0.67 \\
\hline HIV RNA < 400 copies/ml, n (\%) & $58(72)$ & $61(63)$ & $46(62)$ & $15(65)$ & 0.26 & 0.45 & 1.0 \\
\hline HCV genotype 3, n (\%) & $13(16)$ & $34(35)$ & $18(25)$ & $16(64)$ & 0.005 & $<.0001$ & $<.0001$ \\
\hline Median HCV RNA (IQR), logIU/ml & $5.97(5.65-6.50)$ & $6.30(6.00-6.72)$ & $6.22(5.80-6.64)$ & $6.69(6.27-7.06)$ & 0.003 & 0.0003 & 0.004 \\
\hline Median ALT (IQR), U/I & $67(40-119)$ & $87(54-130)$ & $83(51-121)$ & $113(84-132)$ & 0.04 & 0.01 & 0.03 \\
\hline Median AST (IQR), U/I & $56(37-78)$ & $77.5(50-104)$ & $70(48-102)$ & $78(59-105)$ & 0.001 & 0.003 & 0.33 \\
\hline $\begin{array}{l}\text { Median alkaline phosphase (IQR), } \\
\text { U/I }\end{array}$ & $90(70-115)$ & $89(69-112)$ & $90(72-113)$ & $80(65-95)$ & 0.46 & 0.27 & 0.15 \\
\hline Median GGT (IQR), U/I & $71(41-139)$ & $87(43-196)$ & $92(44-198)$ & $73(30-180)$ & 0.09 & 0.09 & 0.19 \\
\hline Median glycemia (IQR), mmol// & $4.80(4.30-5.45)$ & $4.92(4.30-5.22)$ & $4.80(4.30-5.20)$ & $4.90(4.35-5.26)$ & 0.79 & 0.96 & 0.97 \\
\hline Glycemia $\geq 5.6$ mmol/l, n (\%) & $16(21)$ & $17(17)$ & $12(16)$ & $5(21)$ & 0.56 & 0.77 & 0.76 \\
\hline Glycemia $\geq 7.0$ mmol/l, n (\%) & $1(1)$ & $6(6)$ & $6(8)$ & $0(0)$ & 0.14 & 0.08 & 0.33 \\
\hline $\begin{array}{l}\text { Median total cholesterol (IQR), } \\
\mathrm{mmol} / \mathrm{l}\end{array}$ & $4.40(3.73-5.33)$ & $4.00(3.30-4.79)$ & $4.01(3.30-5.03)$ & $3.72(3.06-4.37)$ & 0.01 & 0.02 & 0.30 \\
\hline $\begin{array}{l}\text { Median triglycerides (IQR), } \\
\mathrm{mmol} / / \mathrm{l}\end{array}$ & $1.47(0.97-2.08)$ & $1.51(0.99-2.20)$ & $1.53(1.04-2.24)$ & $1.23(0.90-1.74)$ & 0.86 & 0.51 & 0.28 \\
\hline Triglycerides $\geq 1.7 \mathrm{mmol} / \mathrm{l}, \mathrm{n}(\%)$ & $30(40)$ & $30(33)$ & $23(33)$ & $7(29)$ & 0.33 & 0.56 & 0.80 \\
\hline Fibrosis F3-F4, n (\%) & $12(15)$ & $31(30)$ & $25(33)$ & $6(23)$ & 0.01 & $<0.001$ & 1.0 \\
\hline $\begin{array}{l}\text { Metavir score activity } \mathrm{A} 2 / \mathrm{A} 3 \\
\mathrm{n}(\%)\end{array}$ & $21(26)$ & $34(33)$ & $29(38)$ & $5(19)$ & 0.28 & 0.11 & 0.09 \\
\hline
\end{tabular}




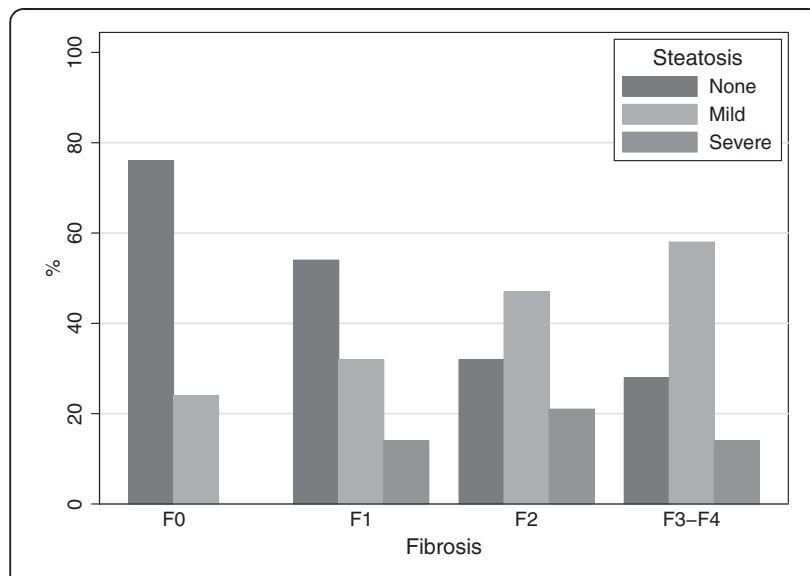

Figure 1 Distribution of steatosis according to fibrosis index in 184 HIV-HCV coinfected patients treated with antiretroviral therapy. Steatosis is defined as mild ( $<33 \%$ of hepatocytes affected) or severe ( $>33 \%$ of hepatocytes affected).

After adjustment for the period of biopsy, neither the type of ART nor the duration of exposure to a specific antiretroviral agent or class of antiretroviral was related to HS (Table 3). The same results were observed in separate analyses among patients presenting genotype 3, or another genotype (Tables 4 and 5).

In the multivariate analysis, only two independent factors remained associated with an increased risk of HS: HCV genotype 3 (odds ratio [OR], 2.6; 95\% confidence intervals [CI], 1.1-6.3), and HCV RNA load (OR, 2.2 per 1 log higher; 95\% CI, 1.2-3.8). Using a multivariate polytomous logistic regression model, $\mathrm{HCV}$ genotype 3 and HCV RNA load were moderately associated with mild steatosis and strongly associated with severe steatosis (Table 6).

\section{Discussion}

Hepatic steatosis has emerged as a major comorbidity in HIV-HCV coinfected patients [13,35]. In this retrospective observational study of $184 \mathrm{HIV}-\mathrm{HCV}$ coinfected patients ART-treated but untreated for $\mathrm{HCV}$ at the time of liver biopsy, HS was present in about half patients (55\%), which is similar to rates of $24-75 \%$ found in other studies of HIV-HCV coinfected and HCV monoinfected patients [12,14-23,36]. In multivariate analysis, HS and its severity were only significantly associated with $\mathrm{HCV}$ genotype 3 and HCV viral load. Neither the type of ART, nor their prolonged duration of exposure with a median of near five years were related to steatosis. Moreover,

Table 3 The effects on steatosis of exposure to specific antiretroviral medication in 184 HIV-HCV coinfected patients

\begin{tabular}{|c|c|c|c|c|c|}
\hline Antiretrovirals & $n$ & $\begin{array}{l}\text { Exposure to ARV } \\
\text { Adjusted OR' }(95 \% \mathrm{Cl})\end{array}$ & $p$ & $\begin{array}{l}\text { Cumulative exposure duration } \\
\text { (per } 1 \text { year increase) } \\
\text { Adjusted OR }(95 \% \mathrm{Cl})\end{array}$ & $p$ \\
\hline $\begin{array}{l}\text { Nucleoside reverse } \\
\text { transcriptase inhibitors }\end{array}$ & 184 & $\mathrm{NE}$ & & $1.05(0.96-1.16)$ & 0.30 \\
\hline zidovudine & 144 & $1.11(0.54-2.30)$ & 0.77 & $1.03(0.91-1.16)$ & 0.65 \\
\hline lamivudine & 161 & $1.10(0.44-2.77)$ & 0.82 & $1.01(0.88-1.17)$ & 0.84 \\
\hline stavudine & 114 & $0.96(0.51-1.78)$ & 0.88 & $1.05(0.90-1.24)$ & 0.54 \\
\hline didanosine & 105 & $1.20(0.66-2.18)$ & 0.57 & $1.04(0.85-1.27)$ & 0.70 \\
\hline zalcitabine & 22 & $1.68(0.60-4.72)$ & 0.33 & $1.50(0.68-3.34)$ & 0.31 \\
\hline tenofovir & 24 & $0.87(0.33-2.27)$ & 0.78 & $1.19(0.69-2.07)$ & 0.53 \\
\hline abacavir & 24 & $0.55(0.22-1.39)$ & 0.20 & $0.98(0.69-1.41)$ & 0.94 \\
\hline Protease inhibitors & 126 & $1.15(0.59-2.24)$ & 0.67 & $1.06(0.90-1.25)$ & 0.50 \\
\hline ritonavir & 55 & $0.90(0.46-1.75)$ & 0.75 & $0.96(0.71-1.28)$ & 0.76 \\
\hline indinavir & 68 & $0.94(0.51-1.74)$ & 0.84 & $1.14(0.87-1.47)$ & 0.34 \\
\hline nelfinavir & 47 & $0.96(0.48-1.89)$ & 0.91 & $1.12(0.79-1.59)$ & 0.54 \\
\hline saquinavir & 31 & $0.91(0.41-2.00)$ & 0.81 & $0.72(0.45-1.14)$ & 0.16 \\
\hline lopinavir-ritonavir & 17 & $0.55(0.19-1.63)$ & 0.28 & $0.86(0.54-1.37)$ & 0.52 \\
\hline atazanavir & 8 & $0.76(0.17-3.43)$ & 0.72 & $0.99(0.35-2.81)$ & 0.98 \\
\hline $\begin{array}{l}\text { Non-nucleoside reverse } \\
\text { transcriptase inhibitors }\end{array}$ & 79 & $0.93(0.50-1.74)$ & 0.81 & $1.17(0.88-1.55)$ & 0.27 \\
\hline efavirenz & 51 & $1.34(0.67-2.69)$ & 0.40 & 1.19 (0.88-1.63) & 0.26 \\
\hline nevirapine & 44 & $0.67(0.33-1.35)$ & 0.26 & $1.24(0.77-2.00)$ & 0.36 \\
\hline
\end{tabular}

${ }^{\circ}$ Adjusted for period of liver biopsy.

Abbreviations: $\mathrm{OR}$, odds ratio; $\mathrm{Cl}$, confidence intervals; $\mathrm{NE}$, not estimable. 
Table 4 The effects on steatosis of exposure to specific antiretroviral medication in 184 HIV-HCV coinfected patients according to the genotype

\begin{tabular}{|c|c|c|c|c|c|c|c|}
\hline & & All patients $(n=184)$ & & Genotype $3(n=47)$ & & Other genotype $(n=132)$ & \\
\hline Antiretrovirals & $n$ & Adjusted $\mathrm{OR}^{\circ}(95 \% \mathrm{Cl})$ & $p$ & Adjusted $\mathrm{OR}^{\circ}(95 \% \mathrm{Cl})$ & $p$ & Adjusted $\mathrm{OR}^{\circ}(95 \% \mathrm{Cl})$ & $p$ \\
\hline NRTI & 184 & $\mathrm{NE}$ & & $\mathrm{NE}$ & & $\mathrm{NE}$ & \\
\hline zidovudine & 144 & $1.11(0.54-2.30)$ & 0.77 & $0.91(0.22-3.82)$ & 0.90 & $1.42(0.58-3.49)$ & 0.45 \\
\hline lamivudine & 161 & $1.10(0.44-2.77)$ & 0.82 & $0.50(0.05-5.00)$ & 0.56 & $1.29(0.45-3.74)$ & 0.64 \\
\hline stavudine & 114 & $0.96(0.51-1.78)$ & 0.88 & $0.58(0.14-0.47)$ & 0.46 & $1.05(0.51-2.17)$ & 0.89 \\
\hline didanosine & 105 & $1.20(0.66-2.18)$ & 0.57 & $1.02(0.27-3.93)$ & 0.97 & $1.17(0.58-2.37)$ & 0.66 \\
\hline zalcitabine & 22 & $1.68(0.60-4.72)$ & 0.33 & NE & & $1.29(0.41-4.06)$ & 0.66 \\
\hline tenofovir & 24 & $0.87(0.33-2.27)$ & 0.78 & $0.15(0.01-1.80)$ & 0.13 & $1.44(0.49-4.22)$ & 0.51 \\
\hline abacavir & 24 & $0.55(0.22-1.39)$ & 0.20 & $0.40(0.07-2.40)$ & 0.32 & $0.58(0.18-1.84)$ & 0.35 \\
\hline$\overline{\mathrm{Pl}}$ & 126 & $1.15(0.59-2.24)$ & 0.67 & $0.19-0.02-1.76)$ & 0.15 & $1.46(0.67-3.15)$ & 0.34 \\
\hline ritonavir & 55 & $0.90(0.46-1.75)$ & 0.75 & $0.54(0.13-2.28)$ & 0.40 & $1.04(0.48-2.27)$ & 0.91 \\
\hline indinavir & 68 & $0.94(0.51-1.74)$ & 0.84 & $1.13(0.29-4.41)$ & 0.86 & $0.81(0.39-1.68)$ & 0.57 \\
\hline nelfinavir & 47 & $0.96(0.48-1.89)$ & 0.91 & $0.37(0.09-1.56)$ & 0.18 & $1.19(0.54-2.66)$ & 0.66 \\
\hline saquinavir & 31 & $0.91(0.41-2.00)$ & 0.81 & $0.41(0.10-1.72)$ & 0.22 & $0.94(0.34-2.61)$ & 0.91 \\
\hline lopinavir-ritonavir & 17 & $0.55(0.19-1.63)$ & 0.28 & $0.45(0.02-8.11)$ & 0.59 & $0.67(0.20-2.19)$ & 0.50 \\
\hline atazanavir & 8 & $0.76(0.17-3.43)$ & 0.72 & NE & & $1.70(0.31-9.24)$ & 0.54 \\
\hline NNRTI & 79 & $0.93(0.50-1.74)$ & 0.81 & $0.33(0.08-1.27)$ & 0.11 & $1.38(0.65-2.95)$ & 0.40 \\
\hline efavirenz & 51 & $1.34(0.67-2.69)$ & 0.40 & $0.74(0.17-3.27)$ & 0.69 & $1.77(0.79-4.00)$ & 0.16 \\
\hline nevirapine & 44 & $0.67(0.33-1.35)$ & 0.26 & $0.34(0.08-1.38)$ & 0.13 & $0.80(0.35-1.83)$ & 0.60 \\
\hline
\end{tabular}

${ }^{\circ}$ Adjusted for period of liver biopsy.

Abbreviations: OR, odds ratio; $\mathrm{Cl}$, confidence intervals; $N E$, not estimable.

ART have no differential effect on occurrence of HS according to the genotype 3 compared to others.

We confirmed previously data of higher HS associated with genotype 3 [23]. Here, the rate of severe HS (14\%) was higher in our study compared with $2-9 \%$ found in US studies in HIV-HCV coinfected individuals [12], but was similar with rates found in other studies $[37,38]$, in particular with those conducted in France [39,40]. Several reasons may explain these discrepancies. Whereas most of our patients, and those included in the study of Bauerle et al. [37], were Caucasian and carrying HCV genotype 3, other studies have included a high proportion of Africo-American patients (47-94\%) and patients infected with $\mathrm{HCV}$ genotype 1 [38-45]. It is well-known that HCV-infected Black people have a lower prevalence of HS than Caucasian [41,45-47], probably related to lower visceral adipose tissue $[16,22]$.

HS is a frequent histological finding in patients with chronic hepatitis $\mathrm{C}$ virus infection, particularly among those infected with genotype 3 strain $[24,48,49]$. The prevalence of $26 \%$ of genotype 3 in our study was similar to the prevalence of $18 \%$ reported in the French HepaVIH cohort [50]. It has been postulated that genotype 1 is associated with "metabolic" steatosis rather than "viral" steatosis developed through a direct cytopathologic effect observed especially in genotype 3 infected patients [51-56]. When we examined the factors impacting the level of steatosis on
ART patients, genotype 3, and high $\mathrm{HCV}$ viral load were two independent factors associated with HS in accordance with previous studies $[15,17,19,20]$. Both factors moderately increased the risk of mild steatosis, but were strongly associated with severe steatosis (grade 2 or 3 ).

Other factors such as greater age [18], higher body mass index (BMI) [12,15-18,20,22,38-40,42,44] [23], hyperglycemia [12], lower cholesterolemia [17], and presence of lipodystrophy [17] have also been found to be independently associated with steatosis in coinfected patients. In our study, patients with metabolic syndrome were not more likely to present HS. However, only seven patients had diabetes, and this limited sample size could have prevent to study this risk factor. Moreover, as expected, exposure to PIs and stavudine, were associated with elevated triglycerides ( $p=0.08$ and $p<0.0001$, respectively), but this metabolic abnormality was not a risk factors of HS in our ART-experienced population. According to the lack of data about HOMA scoring, weight and BMI, we probably missed the impact of metabolic steatosis in genotype other than $3[23,41]$. Other limitation of our retrospective study is lack of information about alcohol consumption. Nevertheless, as described by Machado et al., metabolic syndrome and alcohol were not associated to HS. BMI was considered an increasing risk factor but with small magnitude and diabetes as a possible risk factor with no data for HOMA scoring [16,22]. Moreover, the higher percentage 
Table 5 The effects on steatosis of cumulative exposure duration to specific antiretroviral medication in 184 HIV-HCV coinfected patients according to the genotype

\begin{tabular}{|c|c|c|c|c|c|c|}
\hline & All patients $(n=184)$ & & Genotype $3(n=47)$ & & Other genotype $(n=132)$ & \\
\hline Antiretrovirals & $\begin{array}{l}\text { Cumulative exposure duration } \\
\text { (per } 1 \text { year increase) } \\
\text { Adjusted OR (95\% Cl) }\end{array}$ & $p$ & $\begin{array}{l}\text { Cumulative exposure duration } \\
\text { (per } 1 \text { year increase) } \\
\text { Adjusted OR }(95 \% \mathrm{Cl})\end{array}$ & $p$ & $\begin{array}{l}\text { Cumulative exposure duration } \\
\text { (per } 1 \text { year increase) } \\
\text { Adjusted OR }(95 \% \mathrm{Cl})\end{array}$ & $p$ \\
\hline $\begin{array}{l}\text { Nucleoside reverse } \\
\text { transcriptase inhibitors }\end{array}$ & $1.05(0.96-1.16)$ & 0.30 & $1.07(0.85-1.35)$ & 0.55 & $1.03(0.92-1.15)$ & 0.64 \\
\hline zidovudine & $1.03(0.91-1.16)$ & 0.65 & $1.01(0.81-1.27)$ & 0.92 & $1.00(0.86-1.17)$ & 0.98 \\
\hline lamivudine & $1.01(0.88-1.17)$ & 0.84 & $0.99(0.75-1.32)$ & 0.97 & $0.99(0.84-1.17)$ & 0.92 \\
\hline stavudine & $1.05(0.90-1.24)$ & 0.54 & $1.16(0.81-1.68)$ & 0.41 & $0.99(0.81-1.22)$ & 0.94 \\
\hline didanosine & $1.04(0.85-1.27)$ & 0.70 & $1.08(0.64-1.81)$ & 0.77 & $1.04(0.83-1.29)$ & 0.75 \\
\hline zalcitabine & $1.50(0.68-3.34)$ & 0.31 & $\mathrm{NE}$ & & $1.35(0.57-3.16)$ & 0.49 \\
\hline tenofovir & $1.19(0.69-2.07)$ & 0.53 & $0.29(0.03-2.49)$ & 0.26 & $1.46(0.80-2.66)$ & 0.22 \\
\hline abacavir & $0.98(0.69-1.41)$ & 0.94 & $1.14(0.54-2.41)$ & 0.73 & $0.88(0.56-1.41)$ & 0.61 \\
\hline Protease inhibitors & $1.06(0.90-1.25)$ & 0.50 & $1.14(0.82-1.59)$ & 0.44 & $0.98(0.80-1.21)$ & 0.87 \\
\hline ritonavir & $0.96(0.71-1.28)$ & 0.76 & $0.88(0.45-1.74)$ & 0.72 & $1.00(0.71-1.40)$ & 0.98 \\
\hline indinavir & $1.14(0.87-1.47)$ & 0.34 & $\mathrm{NE}$ & & $0.89(0.63-1.25)$ & 0.50 \\
\hline nelfinavir & $1.12(0.79-1.59)$ & 0.54 & $1.06(0.63-1.76)$ & 0.83 & $1.11(0.66-1.87)$ & 0.68 \\
\hline saquinavir & $0.72(0.45-1.14)$ & 0.16 & $0.67(0.33-1.36)$ & 0.26 & $0.54(0.25-1.19)$ & 0.13 \\
\hline lopinavir-ritonavir & $0.86(0.54-1.37)$ & 0.52 & $0.90(0.13-6.28)$ & 0.92 & $0.89(0.54-1.46)$ & 0.64 \\
\hline atazanavir & $0.99(0.35-2.81)$ & 0.98 & $\mathrm{NE}$ & & $1.53(0.43-5.47)$ & 0.51 \\
\hline $\begin{array}{l}\text { Non-nucleoside reverse } \\
\text { transcriptase inhibitors }\end{array}$ & $1.17(0.88-1.55)$ & 0.27 & $1.04(0.60-1.82)$ & 0.89 & $1.25(0.90-1.75)$ & 0.18 \\
\hline efavirenz & $1.19(0.88-1.63)$ & 0.26 & $1.08(0.56-2.09)$ & 0.82 & $1.28(0.89-1.83)$ & 0.18 \\
\hline nevirapine & $1.24(0.77-2.00)$ & 0.36 & $0.47(0.19-1.20)$ & 0.57 & $1.18(0.67-2.08)$ & 0.56 \\
\hline
\end{tabular}

${ }^{\circ}$ Adjusted for period of liver biopsy.

Abbreviations: $O R$, odds ratio; $\mathrm{Cl}$, confidence intervals; $\mathrm{NE}$, not estimable.

of genotype 3 reflect the association between $\mathrm{HS}$ and $\mathrm{HCV}$ viral parameters.

Many antiretroviral drugs have been associated with hepatic damage [57-59]. It has been suggested that steatosis due to an accumulation of fatty acids in the hepatocytes could be a consequence of mitochondrial dysfunction, secondary to drugs or viruses inducing oxidative stress [60]. The effect of the drug class and drugs within classes on HS in HIV-HCV coinfected patients remain unclear. Previously, some studies reported no significant association between HS and ART as in our study $[12,15,16,18,41]$. When focusing on the use of stavudine, a medication closely linked with HS and lipodystrophy syndrome resulting from mitochondrial damage, Sulkowski et al. [45] found that stavudine exposure was a risk factor for steatosis like in the study of Borghi et al., whereas no such association was found for this drug as well as the D-drug group of antiretrovirals (didanosine, zalcitabine) in other studies [23,38,41,42,61,62]. Recently, in a meta-analysis of the risk factors associated with HS in HIV-HCV patients, Machado et al. failed to find any association with antiretrovirals of any class and HS as well as in our study [16,22]. Moreover, Woreta et al., showed in a study including a majority of Black patients $(87 \%)$ with $94 \%$ genotype 1, the lack of association with antiretroviral drugs with a median cumulative drug exposure similar to ours [41]. Despite its relatively small sample size, our study had a statistical power of $80 \%$ to detect an increased risk of steatosis of 3 for the antiretroviral drugs used less frequently such as abacavir, tenofovir and lopinavir. We could hypothesize that discrepancies with other studies were linked to the differential prevalence of Caucasion subjects, of metabolic characteristics and frequency of genotype 1

Table 6 Results from multivariate polytomous logistic regression analyses of factors associated with mild ( $<33 \%$ of hepatocytes affected ) and severe ( $>33 \%$ of hepatocytes affected) steatosis in 184 HIV-HCV coinfected patients treated with antiretroviral therapy

\begin{tabular}{lllll}
\hline & Mild steatosis AOR $(\mathbf{9 5 \% C l )}$ & $\boldsymbol{p}$ & Severe steatosis AOR (95\%Cl) & $\boldsymbol{p}$ \\
\hline HCV genotype 3 & $1.76(0.72-4.30)$ & 0.22 & $19.51(4.49-84.73)$ & $<0.0001$ \\
\hline HCV RNA (per 1 log10 increase) & $1.80(1.02-3.16)$ & 0.04 & $14.86(3.79-58.22)$ & 0.0001 \\
\hline
\end{tabular}

Abbreviations: $\mathrm{AOR}$, adjusted odds ratio; $\mathrm{Cl}$, confidence intervals. 
and 3. Borghi et al. evocated a putative role of ART in the occurrence of HS in patients infected with genotypes other than 3 [23] but in our study, the impact of ART on HS was not different between genotype 3 and the others.

In conclusion, for our Caucasian cohort predominantly infected with genotype-HCV 1 , hepatic steatosis in HIV-HCV coinfected patients receiving antiretroviral therapy is associated with HCV-related factors particularly in genotype 3 patients but not antiretrovirals. Nevertheless, as showed in our study, ART seems play a minor role in HS since the choose and use of more "metabolically friendly" antiretroviral drugs. Overall, we found only viral parameters, HCV genotype 3 , and $\mathrm{HCV}$ RNA value, which were strongly associated with $\mathrm{HS}$, particularly a severe steatosis. Among HIV-HCV coinfected patients receiving ART and who had never been treated for HCV, neither the type of drugs nor the duration of exposure was related to HS whatever the genotype.

\section{Abbreviations}

HIV: human immunodeficiency virus; HCV: hepatitis C virus; ART: antiretroviral therapy; ALT: alanine aminotransferase; AST: aspartate aminotransferase; GGT: gammaglutamyl transferase; IQR: interquartile range; NRTI: nucleoside reverse transcriptase inhibitor; PI: protease inhibitor; NNRTI: non-nucleoside reverse transcriptase inhibitor; OR: odds ratio; $\mathrm{Cl}$ : confidence intervals; IVDU: intravenous drug use; AOR: adjusted odds ratio; NE: not estimable.

\section{Competing interests}

The authors declare that they have no competing interests.

\section{Acknowledgements}

English language assistance for the preparation of this manuscript was provided by Andrea Bothwell of inScience Communications.

\section{Author details}

${ }^{1}$ Service de Médecine Interne et Immunologie Clinique, Assistance PubliqueHôpitaux de Paris, INSERM UMR_S 996, Université Paris Sud, Hôpital Antoine Béclère, 157, rue de la Porte de Trivaux, 92141, Clamart, France. ${ }^{2}$ Service des Maladies Infectieuses et Tropicales, Hôpital Pitié-Salpêtrière, Université Pierre et Marie Curie, APHP, 45/83 Boulevard de I'Hôpital, 75013, Paris, France. ${ }^{3}$ Departement of Infectious Disease, Hanoi Medical University, 01, Ton That Tung Street, Hanoi, Vietnam. ${ }^{4}$ Departement of Internal Medicine, Hospital National Iranian oil company, Hafez Avenue, Tehran, Iran. ${ }^{5}$ INSERM U943, UPMC Univ Paris 06, UMR 5943, Paris, F-75013, France. 'Service de Maladies Infectieuses et Tropicales, 103 Grande-Rue de la Croix-Rousse, Hôpital de la Croix-Rousse, Hospices Civils de Lyon, 69317 Lyon cedex 04, Paris, France. ${ }^{7}$ Service d'Anatomopathologie, Hôpital Pitié-Salpêtrière, Université Pierre et Marie Curie, APHP, 45/83 Boulevard de I'Hôpital, 75013, Paris, France. ${ }^{8}$ Service d'Anatomopathologie, Hôpital Saint-Louis, Université Denis Diderot, APHP, 1, avenue Claude Vellefaux, 75010, Paris, France. ${ }^{9}$ Service des Maladies Infectieuses et Tropicales, Hôpital Saint-Louis, Université Denis Diderot, APHP, 1, avenue Claude Vellefaux, 75010, Paris, France.

\section{Authors' contributions}

VM conceived the study, collected data of patients, participated in its design and coordination and drafted the manuscript. TDNT and ZM collected the data and helped to draft the manuscript. MG made the statistical analysis and helped to draft the manuscript. PM and MAV helped to draft the manuscript. FC and PB made the histological analysis of liver biopsy. CK and EC participated in the design of the study and helped to draft the manuscript. All authors read and approved the final manuscript.

\section{Financial disclosure}

The authors have no commercial links or other associations that might pose a conflict of interest (e.g. pharmaceutical stock ownership, consultancy, advisory board membership, relevant patents, or research funding) relevant to this study.

\section{Statement naming sources of financial support (including grant numbers)}

None

Received: 24 October 2011 Accepted: 10 April 2012

Published: 10 April 2012

\section{References}

1. Martin-Carbonero L, Benhamou Y, Puoti M, Berenguer J, Mallolas J, Quereda C, Arizcorreta A, Gonzalez A, Rockstroh J, Asensi V et al: Incidence and predictors of severe liver fibrosis in human immunodeficiency virus-infected patients with chronic hepatitis C: a European collaborative study. Clin Infect Dis 2004 38(1):128-133. Epub 2003 Dec 2008.

2. Mehta SH, Thomas DL, Torbenson M, Brinkley S, Mirel L, Chaisson RE, Moore $\mathrm{RD}$, Sulkowski MS: The effect of antiretroviral therapy on liver disease among adults with HIV and hepatitis C coinfection. Hepatology 2005, 41(1):123-131.

3. Qurishi N, Kreuzberg C, Luchters G, Effenberger W, Kupfer B, Sauerbruch T, Rockstroh JK, Spengler U: Effect of antiretroviral therapy on liver-related mortality in patients with HIV and hepatitis $C$ virus coinfection. Lancet 2003, 362(9397):1708-1713.

4. Lauer GM, Walker BD: Hepatitis C virus infection. N Engl J Med 2001, 345 (1):41-52.

5. Graham CS, Baden LR, Yu E, Mrus JM, Carnie J, Heeren T, Koziel MJ: Influence of human immunodeficiency virus infection on the course of hepatitis $C$ virus infection: a meta-analysis. Clin Infect Dis 2001, 33(4):562-569.

6. Macias J, Castellano V, Merchante N, Palacios RB, Mira JA, Saez C, Garcia-Garcia JA, Lozano F, Gomez-Mateos JM, Pineda JA: Effect of antiretroviral drugs on liver fibrosis in HIV-infected patients with chronic hepatitis C: harmful impact of nevirapine. AIDS 2004, 18(5):767-774.

7. Qurishi N, Kreuzberg C, Luchters G, Effenberger W, Kupfer B, Sauerbruch T, Rockstroh JK, Spengler U: Effect of antiretroviral therapy on liver-related mortality in patients with HIV and hepatitis $C$ virus coinfection. Lancet 2003, 362(9397):1708-1713.

8. Mohsen AH, Easterbrook PJ, Taylor C, Portmann B, Kulasegaram R, Murad S, Wiselka M, Norris S: Impact of human immunodeficiency virus (HIV) infection on the progression of liver fibrosis in hepatitis $C$ virus infected patients. Gut 2003, 52(7):1035-1040.

9. Soriano V, Martin-Carbonero L, Garcia-Samaniego J, Puoti M: Mortality due to chronic viral liver disease among patients infected with human immunodeficiency virus. Clin Infect Dis 2001, 33(10):1793-1795.

10. Thein HH, Yi Q, Dore GJ, Krahn MD: Natural history of hepatitis C virus infection in HIV-infected individuals and the impact of HIV in the era of highly active antiretroviral therapy: a meta-analysis. AIDS 2008, 22 (15):1979-1991.

11. Bica I, McGovern B, Dhar R, Stone D, McGowan K, Scheib R, Snydman DR: Increasing mortality due to end-stage liver disease in patients with human immunodeficiency virus infection. Clin Infect Dis 2001, 32(3):492-497.

12. Sulkowski MS, Mehta SH, Torbenson M, Afdhal NH, Mirel L, Moore RD, Thomas DL: Hepatic steatosis and antiretroviral drug use among adults coinfected with HIV and hepatitis C virus. AIDS 2005, 19(6):585-592.

13. Pol S, Lebray P, Vallet-Pichard A: HIV infection and hepatic enzyme abnormalities: intricacies of the pathogenic mechanisms. Clin Infect Dis 2004, 38(Suppl 2):S65-S72.

14. Sterling RK, Contos MJ, Smith PG, Stravitz RT, Luketic VA, Fuchs M, Shiffman ML, Sanyal AJ: Steatohepatitis: Risk factors and impact on disease severity in human immunodeficiency virus/hepatitis $C$ virus coinfection. Hepatology 2008, 47(4):1118-1127.

15. Bani-Sadr F, Carrat F, Bedossa P, Piroth L, Cacoub P, Perronne C, Degott C, Pol S: Hepatic steatosis in HIV-HCV coinfected patients: analysis of risk factors. AIDS 2006, 20(4):525-531.

16. Gaslightwala I, Bini EJ: Impact of human immunodeficiency virus infection on the prevalence and severity of steatosis in patients with chronic hepatitis C virus infection. J Hepatol 2006, 44(6):1026-1032. 
17. Marks KM, Petrovic LM, Talal AH, Murray MP, Gulick RM, Glesby MJ: Histological findings and clinical characteristics associated with hepatic steatosis in patients coinfected with HIV and hepatitis C virus. J Infect Dis 2005, 192(11):1943-1949. Epub 2005 Nov 1942.

18. Monto A, Dove LM, Bostrom A, Kakar S, Tien PC, Wright TL: Hepatic steatosis in HIV/hepatitis C coinfection: prevalence and significance compared with hepatitis C monoinfection. Hepatology 2005, 42(2):310-316.

19. McGovern BH, Ditelberg JS, Taylor LE, Gandhi RT, Christopoulos KA, Chapman S, Schwartzapfel B, Rindler E, Fiorino AM, Zaman MT, et al: Hepatic steatosis is associated with fibrosis, nucleoside analogue use, and hepatitis $C$ virus genotype 3 infection in HIV-seropositive patients. Clin Infect Dis 2006, 43(3):365-372

20. Neau D, Winnock M, Castera L, Bail BL, Loko MA, Geraut L, Dupon M, Ragnaud $J M$, Lacoste D, Lafon ME, et al: Prevalence of and factors associated with hepatic steatosis in patients coinfected with hepatitis $C$ virus and HIV: Agence Nationale pour la Recherche contre le SIDA et les hepatites virales CO3 Aquitaine Cohort. J Acquir Immune Defic Syndr 2007, 45(2):168-173.

21. Sanchez-Conde M, Berenguer J, Miralles P, Alvarez F, Carlos Lopez J, Cosin J, Pilar C, Ramirez M, Gutierrez I, Alvarez E: Liver biopsy findings for HIVinfected patients with chronic hepatitis $C$ and persistently normal levels of alanine aminotransferase. Clin Infect Dis 2006, 43(5):640-644.

22. Castera L, Loko MA, Le Bail B, Coffie $P$, De Ledinghen V, Trimoulet $P$, Winnock M, Dabis F, Neau D: Hepatic steatosis in HIV-HCV coinfected patients in France: comparison with HCV monoinfected patients matched for body mass index and HCV genotype. Aliment Pharmacol Ther 2007, 26(11-12):1489-1498.

23. Borghi V, Puoti M, Mussini C, Bellelli S, Angeletti C, Sabbatini F, Prati F, Cossarizza A, Esposito R: HIV coinfection and antiretroviral therapy enhances liver steatosis in patients with hepatitis $\mathrm{C}$, but only in those infected by HCV genotype other than 3. Antivir Ther 2008, 13(8):1057-1065.

24. Monto A, Alonzo J, Watson JJ, Grunfeld C, Wright TL: Steatosis in chronic hepatitis C: relative contributions of obesity, diabetes mellitus, and alcohol. Hepatology 2002, 36(3):729-736.

25. Sanyal AJ: Review article: non-alcoholic fatty liver disease and hepatitis C-risk factors and clinical implications. Aliment Pharmacol Ther 2005, 22 (Suppl 2):48-51.

26. Hourigan LF, Macdonald GA, Purdie D, Whitehall VH, Shorthouse C, Clouston A, Powell EE: Fibrosis in chronic hepatitis C correlates significantly with body mass index and steatosis. Hepatology 1999, 29(4):1215-1219.

27. Hu KQ, Kyulo NL, Esrailian E, Thompson K, Chase R, Hillebrand DJ, Runyon BA: Overweight and obesity, hepatic steatosis, and progression of chronic hepatitis C: a retrospective study on a large cohort of patients in the United States. J Hepatol 2004, 40(1):147-154

28. Sanyal AJ, Contos MJ, Sterling RK, Luketic VA, Shiffman ML, Stravitz RT, Mills AS: Nonalcoholic fatty liver disease in patients with hepatitis $C$ is associated with features of the metabolic syndrome. Am J Gastroenterol 2003, 98(9):2064-2071.

29. Marks KM, Petrovic LM, Talal AH, Murray MP, Gulick RM, Glesby MJ: Histological findings and clinical characteristics associated with hepatic steatosis in patients coinfected with HIV and hepatitis C virus. J Infect Dis 2005, 192(11):1943-1949.

30. Brinkman K: Editorial response: hyperlactatemia and hepatic steatosis as features of mitochondrial toxicity of nucleoside analogue reverse transcriptase inhibitors. Clin Infect Dis 2000, 31(1):167-169.

31. Balasubramanyam A, Sekhar RV, Jahoor F, Jones PH, Pownall HJ: Pathophysiology of dyslipidemia and increased cardiovascular risk in HIV lipodystrophy: a model of 'systemic steatosis'. Curr Opin Lipidol 2004, 15(1):59-67.

32. Ogedegbe $A E$, Thomas DL, Diehl AM: Hyperlactataemia syndromes associated with HIV therapy. Lancet Infect Dis 2003, 3(6):329-337.

33. Brunt EM, Janney CG, Di Bisceglie AM, Neuschwander-Tetri BA, Bacon BR: Nonalcoholic steatohepatitis: a proposal for grading and staging the histological lesions. Am J Gastroenterol 1999, 94(9):2467-2474

34. The French METAVIR Cooperative Study Group: Intraobserver and interobserver variations in liver biopsy interpretation in patients with chronic hepatitis C. Hepatology 1994, 20(1 Pt 1):15-20.

35. Tien PC, Grunfeld C: The fatty liver in AIDS. Semin Gastrointest Dis 2002, 13 (1):47-54.

36. Bauerle J, Miquel R, Laguno M, Mallolas J, Murillas J, Gatell JM, Walker UA Hepatic steatosis with stavudine in HIV/hepatitis $C$ virus co-infection. AIDS 2005, 19(13):1441-1442.
37. Bauerle J, Miquel R, Laguno M, Mallolas J, Murillas J, Gatell JM, Walker UA Hepatic steatosis with stavudine in HIV/hepatitis C virus co-infection. AIDS 2005, 19(13):1441-1442.

38. Gaslightwala I, Bini EJ: Impact of human immunodeficiency virus infection on the prevalence and severity of steatosis in patients with chronic hepatitis C virus infection. J Hepatol 2006, 44(6):1026-1032

39. Bani-Sadr F, Carrat F, Bedossa P, Piroth L, Cacoub P, Perronne C, Degott C, Pol S: Hepatic steatosis in HIV-HCV coinfected patients: analysis of risk factors. AlDS 2006, 20(4):525-531.

40. Castera L, Loko MA, Le Bail B, Coffie P, De Ledinghen V, Trimoulet P, Winnock M, Dabis F, Neau D: Hepatic steatosis in HIV-HCV coinfected patients in France: comparison with HCV monoinfected patients matched for body mass index and HCV genotype. Aliment Pharmacol Ther 2007, 26(11-12):1489-1498.

41. Woreta TA, Sutcliffe CG, Mehta SH, Brown TT, Higgins $Y$, Thomas DL, Torbenson MS, Moore RD, Sulkowski MS: Incidence and risk factors for steatosis progression in adults coinfected with HIV and hepatitis $C$ virus. Gastroenterology 2011, 140(3):809-817

42. Marks KM, Petrovic LM, Talal AH, Murray MP, Gulick RM, Glesby MJ: Histological findings and clinical characteristics associated with hepatic steatosis in patients coinfected with HIV and hepatitis C virus. J Infect Dis 2005, 192(11):1943-1949. Epub 2005 Nov 1942.

43. Monto A, Dove LM, Bostrom A, Kakar S, Tien PC, Wright TL: Hepatic steatosis in HIV/hepatitis C coinfection: prevalence and significance compared with hepatitis C monoinfection. Hepatology 2005, 42(2):310-316.

44. Neau D, Winnock M, Castera L, Bail BL, Loko MA, Geraut L, Dupon M, Ragnaud JM, Lacoste D, Lafon ME, et al: Prevalence of and factors associated with hepatic steatosis in patients coinfected with hepatitis $C$ virus and HIV: Agence Nationale pour la Recherche contre le SIDA et les hepatites virales CO3 Aquitaine Cohort. J Acquir Immune Defic Syndr 2007 45(2):168-173.

45. Sulkowski MS, Mehta SH, Torbenson M, Afdhal NH, Mirel L, Moore RD, Thomas DL: Hepatic steatosis and antiretroviral drug use among adults coinfected with HIV and hepatitis C virus. AIDS 2005, 19(6):585-592.

46. Browning JD, Szczepaniak LS, Dobbins R, Nuremberg P, Horton JD, Cohen JC, Grundy SM, Hobbs HH: Prevalence of hepatic steatosis in an urban population in the United States: impact of ethnicity. Hepatology 2004, 40(6):1387-1395.

47. Martin-Carbonero L, Soriano V: Interplay between hepatitis C, liver steatosis and antiretroviral therapy in HIV-infected patients. AIDS 2005, 19 (6):621-623.

48. Castera L, Hezode C, Roudot-Thoraval F, Lonjon I, Zafrani ES, Pawlotsky JM, Dhumeaux D: Effect of antiviral treatment on evolution of liver steatosis in patients with chronic hepatitis C: indirect evidence of a role of hepatitis C virus genotype 3 in steatosis. Gut 2004, 53(3):420-424.

49. Kumar D, Farrell GC, Fung C, George J: Hepatitis C virus genotype 3 is cytopathic to hepatocytes: Reversal of hepatic steatosis after sustained therapeutic response. Hepatology 2002, 36:(5)1266-1272.

50. Loko MA, Salmon D, Carrieri P, Winnock M, Mora M, Merchadou L, Gillet S, Pambrun E, Delaune J, Valantin MA, et al: The French national prospective cohort of patients co-infected with HIV and HCV (ANRS CO13 HEPAVIH): early findings, 2006-2010. BMC Infect Dis 2010, 10:303.

51. Adinolfi LE, Gambardella M, Andreana A, Tripodi MF, Utili R, Ruggiero G: Steatosis accelerates the progression of liver damage of chronic hepatitis $C$ patients and correlates with specific HCV genotype and visceral obesity. Hepatology 2001, 33(6):1358-1364.

52. Castera L, Chouteau P, Hezode C, Zafrani ES, Dhumeaux D, Pawlotsky JM: Hepatitis C virus-induced hepatocellular steatosis. Am J Gastroenterol 2005, 100(3):711-715

53. Clement S, Negro F: Hepatitis C virus: the viral way to fatty liver. $J$ Hepatol 2007, 46(6):985-987.

54. Hezode C, Roudot-Thoraval F, Zafrani ES, Dhumeaux D, Pawlotsky JM: Different mechanisms of steatosis in hepatitis $C$ virus genotypes 1 and 3 infections. J Viral Hepat 2004, 11(5):455-458.

55. Patton HM, Patel K, Behling C, Bylund D, Blatt LM, Vallee M, Heaton S, Conrad A, Pockros PJ, MCHutchison JG: The impact of steatosis on disease progression and early and sustained treatment response in chronic hepatitis C patients. J Hepatol 2004, 40(3):484-490.

56. Rubbia-Brandt L, Quadri R, Abid K, Giostra E, Male PJ, Mentha G, Spahr L, Zarski JP, Borisch B, Hadengue A, et al: Hepatocyte steatosis is a cytopathic effect of hepatitis C virus genotype 3. J Hepatol 2000, 33(1):106-115. 
57. Fortgang IS, Belitsos PC, Chaisson RE, Moore RD: Hepatomegaly and steatosis in HIV-infected patients receiving nucleoside analog antiretroviral therapy. Am J Gastroenterol 1995, 90(9):1433-1436.

58. Sulkowski MS, Mehta SH, Chaisson RE, Thomas DL, Moore RD: Hepatotoxicity associated with protease inhibitor-based antiretroviral regimens with or without concurrent ritonavir. AIDS 2004, 18(17):2277-2284.

59. Y B: Systemic overview of HAART- associated liver enzyme elevations in patients infected with HIV and co-infected with HCV. In: 13 th Conference on Retroviruses and Opportunistic Infections 2006. Denver, CO, US; 2006.

60. Day CP, James OF: Steatohepatitis: a tale of two "hits"?. Gastroenterology 1998, 114(4):842-845.

61. Bauerle J, Laguno M, Mauss S, Mallolas J, Murillas J, Miquel R, Schmutz G, Setzer B, Gatell JM, Walker UA: Mitochondrial DNA depletion in liver tissue of patients infected with hepatitis $C$ virus: contributing effect of HIV infection?. HIV Med 2005, 6(2):135-139.

62. Monto A, Alonzo J, Watson JJ, Grunfeld C, Wright TL: Steatosis in chronic hepatitis C: relative contributions of obesity, diabetes mellitus, and alcohol. Hepatology 2002, 36(3):729-736.

doi:10.1186/1756-0500-5-180

Cite this article as: Martinez et al:: Hepatic steatosis in HIV-HCV

coinfected patients receiving antiretroviral therapy is associated with HCV-related factors but not antiretrovirals. BMC Research Notes 2012 5:180.

\section{Submit your next manuscript to BioMed Central and take full advantage of:}

- Convenient online submission

- Thorough peer review

- No space constraints or color figure charges

- Immediate publication on acceptance

- Inclusion in PubMed, CAS, Scopus and Google Scholar

- Research which is freely available for redistribution 